\title{
CONCEPTUAL FRAMEWORKS OF THE DEVELOPMENT OF BANKING AND INSURANCE INTERACTION IN MODERN CONDITIONS
}

The purpose of the article is to reveal conceptual frameworks for further development of the banking and insurance interaction in order to ensure the growth of the value of banking and insurance business on account of the more effective use of their potentials and opportunities.

It is noted in the article that banking and insurance interaction is manifested as the provision of insurance services through banking institutions - Bancassurance, the provision of banking services through insurance companies - Assurbanking, the provision of integrated services within financial conglomerates - Allfinanz.

In the course of the research, it was determined that the banking channel for the sale of insurance services is the most efficient, and Bancassurance is a system of insurance services sale through the extensive banking network. The necessity and importance of the Bancassurance development, which is actively used in all developed countries, but differs in scale, methods, organizational forms and final financial results, is revealed. This is especially relevant in the context of reforming the regulatory bodies of the state financial market.

Within the study, the advantages and disadvantages of Bancassurance and the prerequisites for its development are revealed. Particular attention is paid to the requirements to insurance companies in the process of the Bancassurance implementation.

It is noted within the article that the interaction of banks and insurance companies can be carried out at different levels, from the level of the cooperation agreement, agency agreement, banking and insurance cooperation, to the level of the corporate control through the mechanism of mergers and acquisitions and financial supermarket.

Within the study the conclusions are made that further development of banking and insurance interaction is conceptually aimed at increasing the role of commercial banks and the formation of "financial supermarkets", in which each customer can meet the needs of bank services, financial consulting, and insurance.

Keywords: banking and insurance interaction, Bancassurance, insurance companies, banking institutions, complex bank insurance.

\section{JEL classification: G21, G22}

Introduction and research problem. At the current stage of economic development, the state supervision of the non-banking sector of the financial market is being reformed in order to ensure transparency, reliability and efficiency of its functioning. Pursuant to the Law of Ukraine "On Amendments to Certain Legislative Acts Concerning the Improvement of Functions on State Regulation of Financial Services Markets", the National Commission for Regulation of Financial Services Markets was liquidated, and its powers were divided between the National Bank of Ukraine (the NBU) and the National Securities and Stock Markets Commission (the NSSMC) (Law of Ukraine No. 79-IX, 2019). As a result, the NBU has become a regulator of insurance, leasing, financial companies, credit unions, pawnshops and credit bureaus, and the NSSMC regulates private pension funds and funds on the construction financing.

Therefore, the activities of insurance companies and banking institutions from July 1, 2020 are controlled by one body, which indicates their functional proximity and meets international standards.

Thus, the supervision of banking institutions and insurance companies by one supervisory authority creates new opportunities for the development of interaction between them. Therefore, there is a need for in-depth study of various options for the relationships between banking institutions and insurance companies and their further application in the domestic financial market.

The world financial science defines the integration process of banking and insurance capital as a concept of banking and insurance interaction. 
Recent publications analysis. Current problems of the implementation of the banking and insurance interaction, as well the ways of its improvement are studied both by domestic and foreign scientists. Theoretical and practical aspects of the improvements of banking and insurance interaction are studied in many scientific works of such scientists as O. G. Agres, V. V. Volkova, A. M. Yermoshenko, Yu. S. Klapkiv, V. M. Kremen, A. B. Loboda, O. V. Cheberyako, and others.

Unsolved parts of the problem. However, it is necessary to disclose the features of banking and insurance interaction, and to consider conceptual foundations of its development and improvement in terms of reforming state regulation of the financial market.

Research goal and questions. The purpose of the study is to reveal conceptual foundations for further development of banking and insurance interaction to ensure the growth of the value of the banking and insurance business through more efficient use of potentials and opportunities of both the banks and insurance companies.

Main findings. In current conditions, the mechanism of the subjects' functioning in the financial market essentially changes due to numerous innovations and increased competition between them. The main phenomenon that characterizes these changes is the integration processes between banks and insurance companies, which involve not only the merger of capitals, but also the offer of fundamentally new services.

Banking and insurance interaction can take place both on the basis of banking institutions and on the grounds of insurance companies. Therefore, its implementation involves the construction of the cross-selling system in the following areas: providing insurance services through banking institutions - Bancassurance, providing banking services through insurance companies Assurbanking (Fig. 1).
Banking and insurance interaction is also implemented within financial conglomerates (Allfinanz), when the association involves production, trust, investment and pension funds. In this case, it is envisaged to combine banking, insurance and financial services by one institution on the basis of convergence of banking, insurance and industrial capital.

Banking and insurance interaction is aimed at providing a package of financial services, which envisage the availability of basic and additional services. As a result, not only the quantitative indicators of the interaction subjects, but also the qualitative characteristics of financial services increase.

Practical implementation of the cross-selling technology of banking and insurance services is considered a fairly new phenomenon in the financial market. However, administrative barriers to joint business development have already been removed in many countries.

Promotion of banking products with the help of insurance companies is almost undeveloped, even the term Assurbanking is not yet generally accepted. It is characterized by the entry into the market of banking services of insurance companies, which form a new process of interaction between two sectors of the financial market and promote the development of innovative mechanisms for the distribution and sale of financial services. Insurance companies interact with banking institutions, primarily in the settlement process, as insurers use bank accounts to obtain insurance premiums and make insurance payments. In addition, there is a practice of issuing plastic cards in the office of the insurance company to obtain insurance compensation, providing insurance services on credit, as well as disseminating information about loans through insurance intermediaries.

Bancassurance is considered a more developed type of banking and insurance interaction, which is

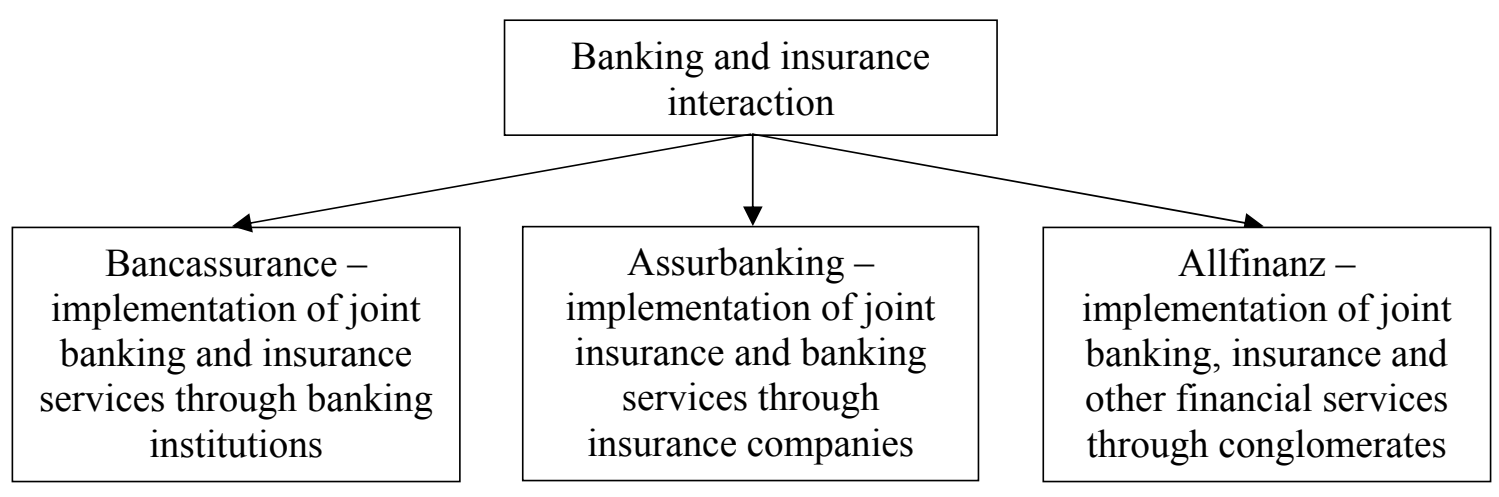

Fig. 1. Types of banking and insurance interaction 
actively used in all developed countries, but differs in scale, methods, organizational forms and final financial results.

Banking channel is the most effective channel of the banking services sale, that is why Bancassurance represents a system of banking services sale through an extensive banking network.

Bancassurance is formed on the basis of banking institutions because:

- the credit market is being actively developed, and a developed network of banking institutions is created;

- there is a high level of automatization of business processes in banks, which accelerates management accounting and financial analysis;

- is definite level of trust to banking institutions is formed;

- banks have got information on the property and financial condition of customers;

- banks actively use investment instruments.

Bancassurance develops between the subjects of financial intermediation, which have significant differences, but as a result of interaction complement each other. The synergetic effect of the combination of banking and insurance opportunities for financial services is manifested in increasing sales of insurance services and optimizing the use of financial resources and information.

As a rule, Bancassurance provides for the implementation through banks of standard and simple underwriting insurance services, which can be both ancillary and additional services. However, the simplest forms of interaction between banks and insurance companies are supplemented by more complex forms, which is due to the interest of banks in new sources of commission on banking insurance programs. Finally, more complex products, which involve the provision of the related insurance services integrated with banking programs, are formed. This can be a mandatory insurance service that is automatically provided by the bank or an additional option of the client's choice.

To ensure their activities, banking institutions also use complex insurance products - BBB Bankers Blanked Bond, which is an important component of Bancassurance (Panchenko, Maslyuk \& Gorylenko, 2020) (Fig. 2).

The essence of Bancassurance is the integration of banks and insurance companies in order to:

- coordinate sales, combine insurance and banking products;

- develop joint channels of their distribution;

- use the same clients' base in order to get profit;

- use the total resources of financial institutions.

As a result, banking and insurance interaction is directed for the increase of the activity efficiency of banks and insurance companies on account of the fullest provision of the needs of clients of financial services (Table 1).

Therefore, Bancassurance provides competitive advantages for the parties of the interaction and improves the position of existing entities in the market through:

- significant expansion of the customers' base;

- increase in the amount of funds without additional costs;

\begin{tabular}{|c|c|c|}
\hline & Bancassurance & \\
\hline$\downarrow$ & $\nabla$ & $\downarrow$ \\
\hline $\begin{array}{c}\text { Banking risk insurance, } \\
\text { including BBB }\end{array}$ & $\begin{array}{c}\text { Insurance of financial risks } \\
\text { of banking institutions }\end{array}$ & $\begin{array}{l}\text { Insurance of clients' risks of } \\
\text { banking institutions }\end{array}$ \\
\hline$\downarrow$ & $\nabla$ & $\downarrow$ \\
\hline $\begin{array}{l}\text { Property insurance in the } \\
\text { bank or by transportation } \\
\text { Insurance of criminal } \\
\text { actions against the bank } \\
\text { Electronic and computer } \\
\text { crime insurance } \\
\text { Professional and } \\
\text { employees' liability } \\
\text { insurance } \\
\text { Insurance of ATMs and } \\
\text { cash in them, etc. }\end{array}$ & $\begin{array}{l}\text { Loans insurance } \\
\text { Investments insurance } \\
\text { Insurance of accepted } \\
\text { guarantees } \\
\text { Less profit insurance } \\
\text { Insurance for reduction of } \\
\text { the insurance level, etc. }\end{array}$ & $\begin{array}{l}\text { Mortgage insurance } \\
\text { Borrower's life insurance } \\
\text { Accident insurance } \\
\text { Income loss insurance } \\
\text { Title insurance, etc. }\end{array}$ \\
\hline
\end{tabular}

Fig. 2. The main types of insurance services which are implemented under the terms and conditions of Bancassurance 


\section{Table 1. Advantages of Bancassurance}

\begin{tabular}{|l|l|l|}
\hline \multicolumn{1}{|c|}{ For banking institutions } & \multicolumn{1}{|c|}{ For insurance companies } & \multicolumn{1}{c|}{ For clients } \\
\hline 1) diversification of the activity & 1) expanding the range of services & 1) wide choice of services \\
2) increase of the clients' loyalty & 2) increase of the customers' base & 2) a possibility to receive banking \\
3) creation of a new source of profit & 3) growth of insurance revenues & and insunce services at one place \\
4) increase of the involved free funds & 4) growth of insurance portfolios & 3) reduction of services cost \\
of insurers & 5) cost reduction for the implementa- & 4) time savings \\
5) cost reduction due to package sale & tion of insurance services & 5) increase of servicing quality \\
of services & 6) quality improvement of insurance & 6) growing trust \\
6) quality improvements of banking & services & 7) growing demand \\
services & 7) image improvement of insurance & \\
7) strengthening the reputation & companies & \\
\hline \multicolumn{2}{|l|}{ Increasing the value of the business through more efficient use of potentials } \\
\hline
\end{tabular}

- formation of new sources of financial receipts;

- obtaining additional profit as a result of interaction;

- risks minimization for the subjects of interaction;

- costs reduction for doing business and providing services;

- optimization of the customers' satisfaction.

The disadvantages of Bancassurance include the following:

- reduced attention to the main activity;

- the need for changes in the legislation and standards;

- possible conflict of interests;

- complicated pricing for services;

- increase in workload for employees;

- different approaches to the definition of trade secrets;

- possible contradictions in the formation of strategic directions of the development.

The process of Bancassurance is a consequence of the transformation of the modern financial market. That is why, it is believed that for the development of integration processes between banking institutions and insurance companies, preconditions both at the level of the financial market, and at the level of credit institutions and insurance companies must be formed.

The main prerequisite for the development of intertwining activities of banks and insurance companies is their functional proximity and the existence of common interests. Banking and insurance have a lot in common, so the struggle for customers and capital markets often intersects. However, for the development and deepening of Bancassurance there must also prerequisites, namely:

- active development of the banking and insurance markets;

- increasing competitiveness level both in the banking and insurance markets, which encourages the growth of the channels of the financial services sale;
- efficiency drop of the functioning of indirect channels of the insurance services sale;

- formation of infrastructural support for effective change of information between insurance and banking segments of the financial market;

- the need to diversify types of financial services for the market subjects;

- ensuring the appropriate level of technical capabilities and automation of business processes of banks and insurance companies;

- availability of the developed corporate culture on the levels of banking institutions and insurance companies;

- availability of the trained personnel for effective work in the conditions of the active development of the banking and insurance business.

International experience shows the importance of the stage of selection of interaction partners, since Bancassurance involves the organization of single business processes, the creation of the unified business processes, the formation of the unified information system and appropriate personnel policy. Therefore, in the process of implementing the strategy of banking and insurance interaction, the in-depth analysis of the mentioned below levels is carried out:

- the level of technological promotion of insurance services;

- the level of automatization of the business processes of banks and insurance companies;

- the level of the personnel training able to work efficiently in the conditions of Bancassurance;

- the level of corporate culture of the interaction subjects.

In modern conditions, an important obstacle to the development of banking and insurance interaction is the low level of automation of the business processes in insurance companies. Therefore, some requirements are put before insurance companies, which they must fulfill.

1) It is important for insurance companies to focus on the maximum volume of sales and revenue 
by improving the quality of customers' servicing. That is why the insurer must be honest in its business, know the needs of its customer, be attentive to the little things and be ahead of customers' expectations.

2) Insurance companies need to actively improve the technical level of the customers' service and introduce digital technologies for insurance policies.

3) Insurance services must be clear, universal and easy in underwriting, which will allow to form package banking and insurance services taking into consideration the needs of customers.

4) The software of insurance companies must be integrated with the software of banking institutions to avoid obstacles by implementing Bancassurance.

In practice, we can meet different levels of interaction between banks and insurance companies (Fig. 3).

The initial level of Bancassurance is concluding the cooperation agreement between an insurance company and a bank, which envisages the provision by the insurance company some services to the bank and its clients.

Some scholars believe that such cooperation cannot be considered Bancassurance, because these agreements don't provide interaction of the sales channels and the creation of common products. However, for the countries, where the financial markets are being formed now, this is an important component of banking and insurance interaction

In Ukraine, this interaction is regulated by the Rules of cooperation between banks and insurers related to lending. Under these Rules, banks and insurers undertake to avoid any concerted and coordinating actions that restrict competition between banks, or between insurers in the relevant markets (The League of Insurance Companies).

The Rules contain the basic principles of cooperation between insurers and banks, special requirements of legislation to their cooperation. The main requirements to the banks' behavior are identified, in particular: informing the insurers, borrowers by the bank; establishing the requirements for the insurers by the bank, checking the compliance of the insurer with the requirements of the bank.

The next level of banking and insurance interaction is an agency agreement with the bank, which provides for the bank to perform the functions of an insurance agent and is aimed at the distribution of insurance services by the banking institution and its network.

Banks that act as insurance agents have the right to freely choose partners-insurers that meet the requirements of the bank.

When a bank acts as an insurance agent or conducts a joint campaign with the insurer to sell a banking and/or insurance product, it may influence the setting of insurance rates under the agreements concluded with the bank's borrowers. If the bank and the insurer combine lending and insurance services into a set of inextricably linked services (single product or package of services), such insurance agreement must meet the requirements of the bank to insurance agreements (The League of Insurance Companies). That is, when concluding agency agreements, banking and insurance interaction significantly expands.

An even deeper level of interaction is banking and insurance cooperation, which provides for the establishment of a contractual association by the partners, in order to form on a contractual basis, the most favored treatment in all spheres of cooperation. This level of banking and insurance interaction requires coordination the joint business on the longterm temporary base.

The next level of banking and insurance interaction is corporate control, which involves the application of a control mechanism through mergers and acquisitions, through which the bank or the

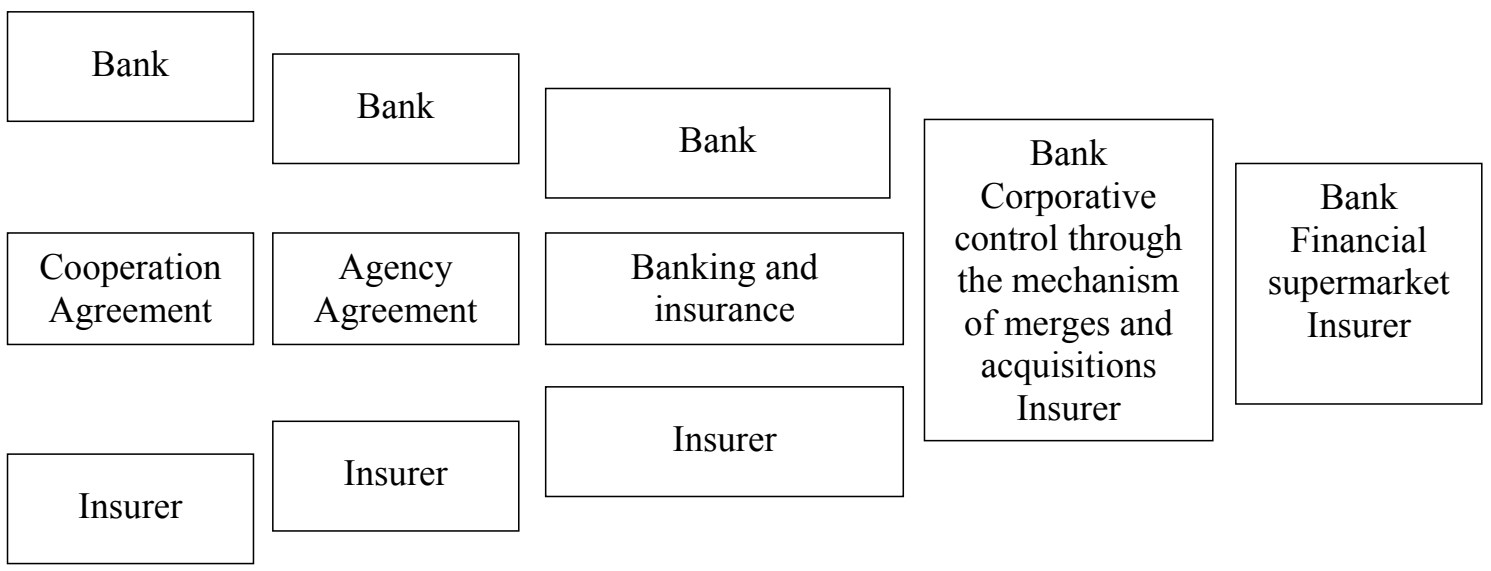

Fig. 3. Levels of the Bancassurance development 
insurance company can achieve its strategic goal. The mechanism of merger and acquisition allows you to effectively use sales channels, to expand and diversify the list of services and the clients' base. This is a widespread and effective strategy of the Bancassurance implementation, which is used in the financial services markets of foreign countries.

The highest level of banking and insurance interaction is a "financial supermarket". The implementation of this level of banking and insurance interaction is possible only by the participation and complementarity of different financial institutions: private pension funds, banks and insurance companies, investment funds, which activities complement each other.

In this case, the subjects of interaction should be closely integrated not only at the level of structural units that provide services to the customers and ensure the sharing of sales channels of financial services, but also at the level of units that do not perform work related to customers (Insurance Case).

Conclusions and further research proposals. Thus, further development of banking and insurance interaction is conceptually aimed at enhancing the role of commercial banks and the formation of "financial supermarkets" based on them in which each client can meet the needs of banking services, financial consulting and insurance.

In Ukraine, there are significant differences in the principles of building the banking and insurance business, as well as there is no legal basis for the establishment of such companies. According to the legal framework, Bancassurance is implemented in Ukraine through cooperation agreements between banks and insurers related to lending, as well as agency agreements. A real form of the Bancassurance development is joint ownership of a bank and an insurance company within a financial-industrial group.

However, the creation of the specialized companies of Bancassurance and financial supermarkets, which ensure the sale of banking and insurance products to individual and corporate clients of banks, as well as provide insurance protection of banks themselves is a promising area of the financial market development.

References

Cheberyako, O. V., \& Loboda, A. B. (2014). Integrated Financial Intermediaries as a Form of Interaction between Banks and Nonbanks. Problems of Economy, 3, 312-318. http://nbuv.gov. ua/UJRN/Pekon_2014_3_43 [in Ukrainian].

Forinsurer. (2021). Results of the insurance market of Ukraine in 2020: premiums reduction to UAH 45 billion and profit growth to UAH 2 billion. https://forinsurer.com/news/21/04/07/39556

Insurance business. Market review. Bancassurance: a strategic direction of the insurance market development in Ukraine https://forinsurer.com/public/04/11/21/1762 [in Ukrainian].

Kremen, V. M. (2011). Bancassurance: Experience of European Countries and Ukraine. Bulletin of Zaporizhzhia National University. Economic Sciences, 3(11), 184-195. https://core.ac.uk/ download/pdf/324245893.pdf [in Ukrainian].

Law of Ukraine No. 79-IX. (2019). On Amendments to Certain Legislative Acts Concerning the Improvement of the Functions on State Regulation of Financial Services Markets. https://zakon. rada.gov.ua/laws/show/79-20\#Text [in Ukrainian].

Panchenko, O. I., Maslyuk, O. Yu., \& Gorylenko, A. S. (2020). Bank risks as an object of insurance in modern conditions.

Problems and Prospects of Economics and Management, 4(24), 146-154. https://doi.org/10.25140/2411-5215-2020-4(24)146-154 [in Ukrainian].

Sadura, O. B., \& Agres, O. G. (2020). Bancassurance as a valuable financial market development instrument. Journal of Lviv Polytechnic National University, Series of Economics and Management Issues, 4(1), 93-100. https://doi.org/10.23939/ semi2020.01.093 [in Ukrainian].

The League of Insurance Companies. Rules of interaction between banks and insurers. insurancebiz.org/upload/doc/dodatok_1_ pravula yzgodjen_amky.pdf [in Ukrainian].

Volkova, V. V., \& Volkova, N. I. (2016). Bancassurance as a modern method of the credit risk minimization. Finances, Accounting, Banks, 1(21), 54-59. http://nbuv.gov.ua/UJRN/Fub_2016_1_7 [in Ukrainian].

Yermoshenko, A. M. (2007). Theoretical and practical aspects of the integration of insurers and banks. https:/essuir.sumdu.edu.ua/ bitstream-download/123456789/53963/5/Yermoshenko_ Intehratsiia.pdf [in Ukrainian].

Базілінська О. Я., Панченко О. I.

\section{КОНЦЕПТУАЛЬНІ ЗАСАДИ РОЗВИТКУ БАНКІВСЬКО-СТРАХОВОЇ ВЗАСМОДІЇ В СУЧАСНИХ УМОВАХ}

Метою статті є розкриття концептуальних засад розвитку банківсько-страхової взаємодії для забезпечення зростання вартості банківського і страхового бізнесу завдяки більш ефективному використанню їхніх потенціалів і можливостей.

У статті зазначено, що банківсько-страхова взаємодія проявляється як надання страхових послуг через банківські установи (Bancassurance), надання банківських послуг через страхові компанії (Assurbanking), надання інтегрованих послуг у межах фінансових конгломератів (Allfinanz).

У процесі дослідження з'ясовано, що банківський канал реалізації страхових послуг є найбільш ефективним i Bancassurance (банкострахування) розвивається між двома суб'єктами фінансового посередництва, які мають суттєві відмінності, але в результаті співпраці доповнюють один одного. 
Розкривається необхідність і значення розвитку банкострахування, яке активно використовується у всіх розвинених країнах, але відрізняється масштабами, методами, організаційними формами і кінцевими фінансовими результатами. Це особливо актуально в умовах реформування органів державного регулювання фінансового ринку.

Розглянуто переваги та недоліки банкострахування, а також передумови його розвитку. Особливу увагу приділено вимогам, які висуваються до страхових компаній у процесі реалізації банкострахування.

У статті зазначено, що співпраця банків і страхових компаній може здійснюватися на різних рівнях - від рівня угоди про співпрацю, агентської угоди, банківсько-страхової кооперації до рівня корпоративного контролю через механізм злиття і поглинання та фінансовий супермаркет.

За результатами дослідження зроблено висновок, що подальший розвиток банківсько-страхової взаємодії концептуально спрямований на підвищення ролі комерційних банків та формування на їхній основі «фінансових супермаркетів», у яких кожен клієнт може задовольнити потреби в банківському обслуговуванні, фінансовому консалтингу та страхуванні.

Ключові слова: банківсько-страхова взаємодія, банкострахування, страхові компанії, банківські установи, комплексне банківське страхування.

Матеріал надійшов 30.04.2021

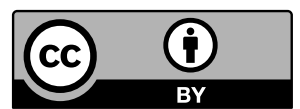

Creative Commons Attribution 4.0 International License (CC BY 4.0) 